\title{
Confronting South Africa's Water Challenge: A DECOMPOSITION ANALYSIS OF WATER INTENSITY
}

\author{
Marcel Kohler* \\ Department of Economics, University of KwaZulu-Natal \\ Accepted: August 2016
}

\begin{abstract}
Water is a vital natural resource, demanding careful management. It is essential for life and integral to virtually all economic activities, including energy and food production and the production of industrial outputs. The availability of clean water in sufficient quantities is not only a prerequisite for human health and well-being but the life-blood of freshwater ecosystems and the many services that these provide. Water resource intensity measures the intensity of water use in terms of volume of water per unit of value added. It is an internationally accepted environmental indicator of the pressure of economic activity on a country's water resources and therefore a reliable indicator of sustainable economic development. The indicator is particularly useful in the allocation of water resources between sectors of the economy since in waterstressed countries like South Africa, there is competition for water among various users, which makes it necessary to allocate water resources to economic activities that are less intensive in their use of water. This study focuses on economy-wide changes in South Africa's water intensity using both decomposition and empirical estimation techniques in an effort to identify and understand the impact of economic activity on changes in the use of the economy's water resources. It is hoped that this study will help inform South Africa's water conservation and resource management policies.
\end{abstract}

Key words: water intensity, decomposition, South Africa

JEL: Q25

\section{$1 \quad$ Introduction}

Bluntly stated, South Africa does not have enough water. South Africa is ranked as the 30th driest country in the world with a mean annual precipitation of $450 \mathrm{~mm}$, just over half the world average of $860 \mathrm{~mm}$. This average conceals the significant variability in rainfall across the country, however, with less than $100 \mathrm{~mm}$ falling along South Africa's west coast and more than $1000 \mathrm{~mm}$ falling on the east coast per year. The country is also susceptible to periodic and sometimes longlasting droughts. To aggravate the situation, the mean annual evaporation varies between $800 \mathrm{~mm}$ and $2000 \mathrm{~mm}$, exceeding the annual rainfall substantially in some areas of the country (DWA, 2013). Indeed, in large parts of South Africa, much of the rain that reaches the ground soon evaporates and re-enters the atmospheric phase of the hydrological cycle. South Africa's groundwater resources are likewise scarce, as most of the country is made up of hard rock formations that do not contain major ground aquifers that can be used on a national scale. It is estimated that only 20 per cent of South Africa's groundwater can currently be used. Groundwater resources are used extensively in rural and arid areas and it is estimated that about one-third of the population are dependent on groundwater for domestic needs (DWA, 2013). With just over 1100 kilolitres of available freshwater for each person each year, and with a population of approximately 46 million, the country is on the threshold of the internationally accepted definition of water stress. Within a few years, population growth will take South Africa below this level. Indeed, South Africa already has less water per person than countries widely considered much drier, such as Namibia and Botswana (UNESCO, 2006).

For an economy, water certainly is an essential resource in providing the necessities of life for its population and as an input in the production of goods and services to meet economic growth and development goals. It is vital therefore that water is utilised optimally in order to manage effectively the delicate balance between resource sustainability and sustainable economic growth. 
Increasing the output of an economy means that more water resources are required as water resources are highly positively correlated with economic output. Conversely, the water resources in a region have a natural limit, making it impossible to supply water without constraints on economic growth. While it is agreed that decreasing water intensity and conservation efforts are the most cost-effective and simplest of the available methods for meeting South Africa's future water needs, there is a lack of consensus pertaining to the actual drivers of economy-wide water intensity changes and the optimal policies required for the effective management of the country's scarce water resources. Over time two approaches to measuring water use intensity have emerged, namely the engineering approach and the economic approach. The engineering approach focuses on the abstraction, storage, distribution, treatment and disposal activities related to the hydrological cycle and its variability. This approach gives rise to recommendations for the implementation of supply-side water resource management measures, such as infrastructure expansion and investment in reducing leakages. On the other hand, the economic focus on water intensity deals with efforts to improve the social gains from water use. It attempts to optimise the benefits of the allocation of an exogenously given amount of water in an economy under alternative institutional policies. The focus of the economic approach is on the analysis of water as a consumption good and as an input in production processes and forms the basis of the introduction of water demand-management policies.

This study examines the economy-wide drivers of water use intensity in South Africa over the period 1980 to 2012 from an economic perspective. The analysis highlights the impact of the level of economic activity on changes in water use intensity and attempts to identify possible factors that affect actual levels of water use within the economy. Water use intensity is an internationally accepted environmental indicator of the pressure of economic activity on a country's water resources and a reliable indicator of sustainable economic development, informing policies of water allocation among competing activities in water-stressed regions (UN ESCAP, 2009). Information obtained from a decomposition and regression analysis of changes in water intensity should help inform South Africa's water conservation and resource management policies.

The remainder of the paper is set out as follows. Section 2 provides an overview of South Africa's water usage and the economic theory behind water use intensity. Section 3 covers a discussion of the decomposition methodology and empirical approach adopted in the study in the examination of changes in South Africa's water use intensity. The results relating to the drivers of changes in the country's water intensity are discussed in section 4 . The final section offers a discussion of policies relevant to the management of South Africa's water resources in the light of the study's findings.

\section{Background}

It is estimated that South Africa's mean annual precipitation runoff is approximately 49 billion $\mathrm{m}^{3}$ per annum of which a mere 10.24 billion $\mathrm{m}^{3}$ is available annually at high assurance. According to the Department of Water Affairs (DWA), 9.5 billion $\mathrm{m}^{3}$ of this available resource is required annually to satisfy the country's total ecological reserve requirement, which includes the key ecosystems, namely the rivers, lakes, wetlands and estuaries requiring protection (DWA, 2013). South Africa's water usage typically comprises surface water (77 per cent), groundwater ( 9 per cent) and re-use of return flows (14 per cent). The water reserve required to satisfy basic human needs ( 25 litres per person per day) translates to 472 million $\mathrm{m}^{3}$ currently (representing 11 per cent of the country's total residential water use in 2012). Annual groundwater usage in South Africa is estimated to be 2 billion $\mathrm{m}^{3}$ although it has been suggested that the potential reliable yield is 5 billion $\mathrm{m}^{3}$ per annum. The annual return flows from irrigation, urban domestic uses and bulk industrial and mining effluents offer re-use opportunities estimated to be close to 1.9 billion $\mathrm{m}^{3}$. These numbers put South Africa's total reliable water yield (with 98 per cent supply assurance) at close to 15 billion $\mathrm{m}^{3}$ at present (DWA, 2013). According to the DWA's Water Authorisation and Registration Management System (WARMS) database, total registered water usage in 2012 was 
estimated at between 15 and 16 billion $\mathrm{m}^{3}$. This implies that South Africa's current water usage exceeds the reliable annual yield, highlighting the urgent need for effective water conservation policies to help address the country's water shortage.

South Africa's water use by economic activity (shown in Figure 1) is dominated by agricultural use for irrigation purposes (63 per cent), livestock watering and nature conservation ( 3 per cent), mining ( 2 per cent), industry ( 9 per cent), commercial and business use ( 7 per cent) and residential use (16 per cent). The per centages indicated are for the year 2012 (DWA, 2013).

Figure 1

South African water use per economic activity: 1980-2012

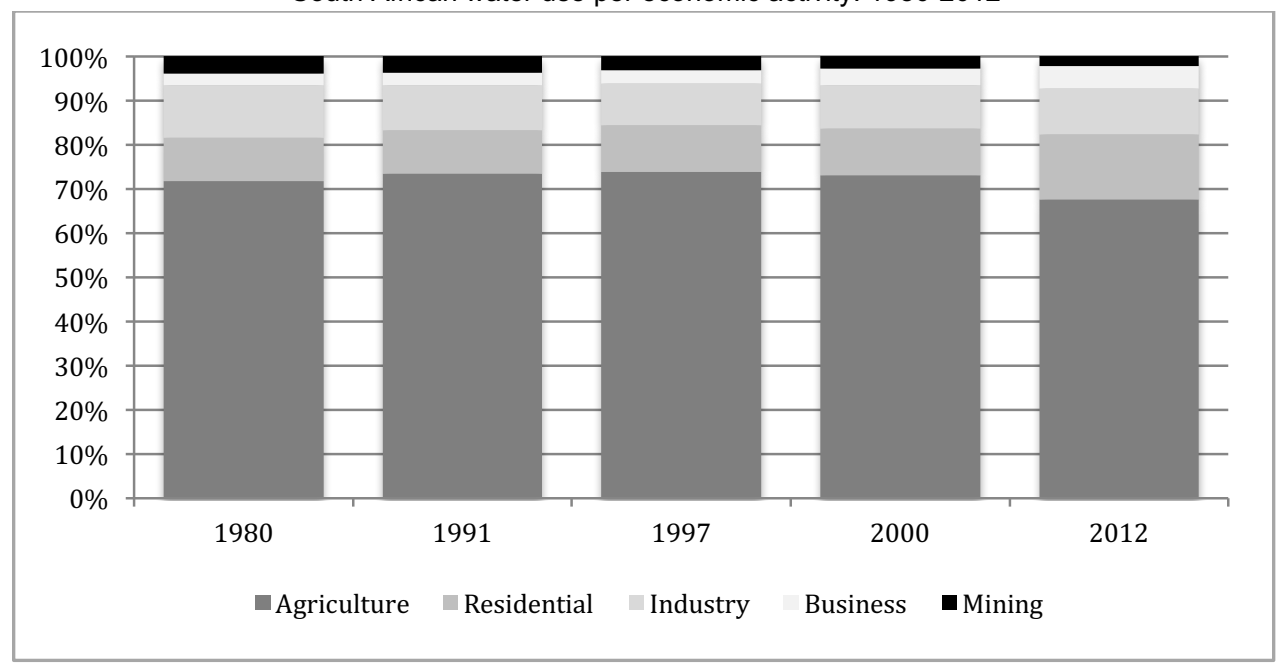

Source: Department of Water Affairs (various publications)

In 1998, the South African government promulgated the National Water Act (DWAF, 1998), which recognised water as a national asset and a strategic resource for the country's economic and social development. The National Water Resource Strategy (DWAF, 2004a) and the Waste Discharge Charge System (WDCS) (DWAF, 2000) were developed to help implement the National Water Act in addressing the management of the country's water resources to meet its development goals. Historically the management of South Africa's water resources has focused on the supply side. More recently, however, the DWAF (2004a:78) has recognised that "the options for further augmentation of water supply by the development of physical infrastructure are limited and in the future attention will have to be on managing the increasing demand for water in order to achieve a sustainable long-term balance between water availability and water requirements". The options for the supply-side management of South Africa's water resources include: inter-basin water transfers, the desalination of seawater and acid mine drainage. These supply-side engineering solutions "are however becoming less viable, and water managers are turning to the attractive solutions offered by demand-side management" (King, 2004:208).

The key to the management of South Africa's scarce water resources therefore lies with demand-side approaches. The South African government recognises this and explicitly states in its National Water Resource Strategy that "water-demand management and water conservation can be achieved through the efficient use of water combined with pollution abatement, re-use and recycling of water and water-efficient technologies" (DWAF, 2004b:6). Water use intensity has its origins in the economic concept of productivity. In economics productivity measures the amount of any given resource that must be expended to produce one unit of a good or particular service. Water use intensity is the inverse of water productivity, which measures the value added generated by one unit of water used. Water productivity gives an indication of the intrinsic value being placed on water. It has low values when water is used for low value purposes, which is generally 
the case when water is abundant and/or undervalued. High values of the indicators are associated with water recycling and improved technology which reduces the amount of water used and therefore abstracted (UN, 2006). Water use intensity per economic activity in South Africa should thus in a similar manner be measured by the volume of water utilised to produce a unit of output, where the output is commonly measured in value added terms (see Table1). In general, the lower the water input requirement per unit of output, the lower the water intensity associated with an economic activity.

Table 1

Water intensity per South African economic activity $\left(\mathrm{m}^{3} / \mathrm{ZAR}\right)$

\begin{tabular}{|c|c|c|c|c|c|}
\hline & 1980 & 1991 & 1997 & 2000 & 2012 \\
\hline \multicolumn{6}{|l|}{ Agriculture } \\
\hline water use (million $\mathrm{m}^{3}$ ) & 9,669 & 10,560 & 11,259 & 11,382 & 11,090 \\
\hline output (R million) & 43.890 & 58.761 & 66.463 & 73.682 & 109.156 \\
\hline $\mathrm{m}^{3} / \mathrm{R}$ & 220 & 179 & 169 & 155 & 102 \\
\hline \multicolumn{6}{|l|}{ Mining } \\
\hline water use (million $\mathrm{m}^{3}$ ) & 532 & 530 & 484 & 430 & 360 \\
\hline output (R million) & 139.706 & 127.830 & 175.670 & 171.824 & 188.238 \\
\hline $\mathrm{m}^{3} / \mathrm{R}$ & 3.81 & 4.15 & 2.76 & 2.50 & 1.91 \\
\hline \multicolumn{6}{|l|}{ Industry } \\
\hline water use (million $\mathrm{m}^{3}$ ) & 1,596 & 1,440 & 1,459 & 1,520 & 1,700 \\
\hline output (R million) & 566.810 & 667.454 & 757.295 & 948.496 & $1,414.106$ \\
\hline $\mathrm{m}^{3} / \mathrm{R}$ & 2.82 & 2.16 & 1.93 & 1.54 & 1.20 \\
\hline \multicolumn{6}{|l|}{ Commerce } \\
\hline water use (million $\mathrm{m}^{3}$ ) & 360 & 428 & 456 & 536 & 850 \\
\hline output (R million) & 633.898 & 786.264 & 924.648 & $1,148.697$ & $2,169.236$ \\
\hline $\mathrm{m}^{3} / \mathrm{R}$ & 0.586 & 0.544 & 0.493 & 0.466 & 0.392 \\
\hline
\end{tabular}

Source: Author's own calculation based on DWA (various), CSIR and Quantec data

In an environmental economic context, the resource intensity concept must, however, be extended to include considerations of quality (UN ESCAP, 2009). Any effort to manage the country's water resources to reduce water use intensity should also take into consideration efforts to maintain or improve water quality in South Africa. Information on water use intensity is important in informing water conservation efforts. The latter term has been defined in various ways in the past. The definition used by Baumann, Boland \& Silms (1980) is most relevant to the present study, namely, water conservation involves a socially beneficial reduction in water use or water loss. In this context information on water use intensity is of central importance in highlighting economic pressures on water resources. Similarly, the conservation definition suggests that the intensity measure should, in addition to reducing water use per unit of activity, make sense economically and socially within an economy (Tate, 2000). In summary, the reduction of water use intensity in South Africa should involve increasing water productivity by reducing the intensity of water use, improving the allocation of water among competing water uses so as to obtain a greater socioeconomic value per drop of water utilised and improving the technical efficiency of water service provision within the country.

Economic factors are among the most important drivers of change in water use intensity. Water has two main uses in an economy: it is utilised directly as a consumption good by households or it is employed as a factor of production in agriculture, forestry, mining, industry and commerce. The theoretical foundations of these uses differ and are discussed separately. Residential demand is the only instance in which water is consumed directly. Residential water competes directly with other items in the household budget of South Africans. Consumer choice can be modeled as utility maximisation given a budget constraint from which a downward sloping demand for water can be derived. A condition for economic efficiency in consumption is that marginal utility must be 
equated for all consumers. This principle is generally achieved in South Africa as all consumers in a given area face the same price for water. Turning to water as an input in production, theoretically its demand is dependent on the demand for the product it is used to produce, the water intensity of the production process and the available water-saving technologies. Water's use in this context should be related to the ratio of its marginal productivity per rand of value added in production relative to that of other inputs, namely, capital, labour, energy and raw materials.

Water has traditionally been regarded as a public good, which makes management strategies of water pricing and allocation an extremely sensitive topic. These strategies are not normally based on economic efficiency but rather on social and distributional criteria such as fairness and/ or equity considerations (Moolman, Blignaut \& Van Eyden, 2006). A variety of mechanisms are used in countries to allocate water resources among competing uses. These range from complete government allocation, to a mixture of market and government allocation, to predominantly market allocation. Dinar, Rosegrant \& Meinzen-Dick (1997) distinguish between four different water allocation mechanisms which include: (1) public (administrative) water allocation, whereby the state decides how much water is allocated to different uses; (2) user-based allocation schemes, extensively used in agricultural irrigation systems; (3) water markets, where trading occurs in water rights; and (4) pricing, where water use is charged. With increasing water scarcity and acknowledgement worldwide that water has an economic value in all its competing uses and as such should be recognised as an economic good (UN, 2006), authorities within countries are increasingly turning to market allocation approaches which include assigning water rights and pricing.

Market prices will result in an efficient and equitable allocation of a good, service or resource if it is correctly priced. Under conditions of economic scarcity, value is attached to water resources and access rights are assigned to water resources. When these rights are traded, a price is negotiated in the market transaction. In economic theory, the optimal combination of inputs, or "economic efficiency", occurs when the marginal prices of each of the factor inputs are equal. If any required input has a very low, or zero price, to the user, as much of that input will be used as is required. Water belongs to a group of materials called common property resources, to which access is nonexclusive, ownership is held in common by the public and prices are very low, or zero. Stated simply, when water prices are low relative to the costs of other inputs and in relation to the costs of developing supplies, water resources will be overused and water intensity will be correspondingly high. Regardless of their origin, low water prices are the enemy of efforts to conserve water use in that there is less incentive for users to recover, recycle and decrease their demand for water, as compared to a situation in which they have to pay more for water (Tate, 2000). Water markets are, however, not suitable pricing strategies for all uses. In the case of household use, water markets will result in high-value users bidding up market clearing prices that will have social costs for low-income consumers in that they will be forced to spend large proportions of their income on water (Moolman et al., 2006).

Generally, water prices are defined as the final price that the end-user pays per cubic metre $\left(\mathrm{m}^{3}\right)$ of water. It is acknowledged, however, that there is no such thing as a single price for water in South Africa and that the end-user price is constructed on the basis of a variety of components, and water tariffs. Currently, end-user prices for water in the country include a "water resource management" charge, a "water resource development and use of water works" charge, a "water research fund" levy, as well as bulk and/or retail water tariffs (Eberhard, 2003). By and large, these charges and tariffs are based on cost recovery principles. The first two charges vary according to geographical area and economic sector and are designed to recover the costs associated with water resource management in the first instance and the construction, operation and maintenance of water supply schemes and infrastructure in the latter case. The third charge is a levy earmarked to fund the operations of the country's water research commission. Bulk tariffs are designed to recover the costs associated with raw water abstraction and bulk water treatment and distribution, while retail water tariffs are designed to recover the costs of reticulation of water to consumers (Eberhard, 2003). Historically, the costs of providing water services in South Africa 
have not been fully recovered. It has been noted in many studies that the final price paid by water users in South Africa does not reflect the value derived from water, the opportunity costs of water use, or the scarcity of water resources (Cummings \& Nercissiantz, 1992; Dinar \& Subramanian,1998; Eberhard, 2003). An excessive quantity of water is utilised in the economy, leaving little to sustain ecosystems and at the same time large quantities of wastewater and pollution are discharged into the country's surface water and groundwater sources.

\section{Water use intensity decomposition analysis}

Figure 2 shows changes in South Africa's aggregate water use intensity for the period 1980 to 2012 (the period for which reliable water use data per broad economic activity could be sourced from the records of the Department of Water Affairs formerly the Department of Water Affairs and Forestry). The trend in the country's water use intensity appears to have been declining over the years. This should not, however, be interpreted as a reduction in water consumption over the study period. Both value added and water consumption increased over the years but the increase in water consumption was lower than the increase in economic output, so the overall water/output ratio decreased.

Figure 2

Aggregate water intensity in South Africa: 1980-2012 (m³/ZAR millions)

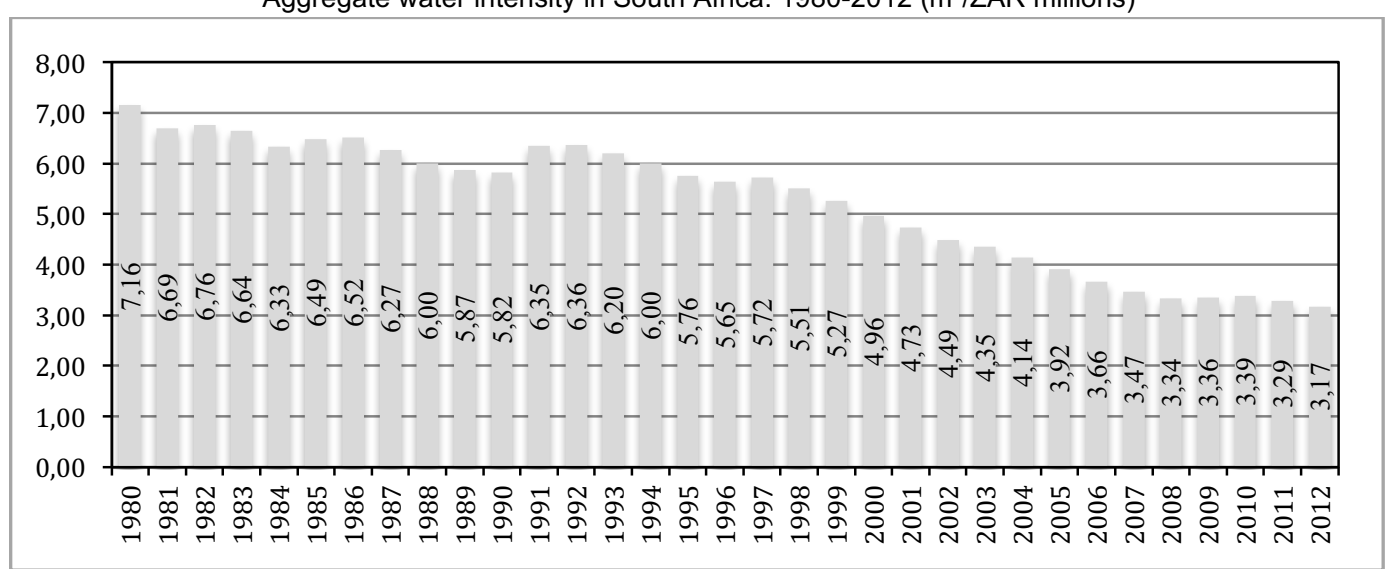

Source: Authors own calculations based on DWAF, DWA, CSIR and Quantec data

The water intensity value shows how many units of water (measured in $\mathrm{m}^{3}$ ) are utilised in the production of economic output (measured in ZAR millions). The total economy decreased its water utilisation in the production of R1 million of output from $7160 \mathrm{~m}^{3}$ in 1980 to $3170 \mathrm{~m}^{3}$ in 2012. In other words, the required water to produce R1 million decreased by 55.7 per cent from 1980 to 2012 , with an average year-on-year decrease of 2.4 per cent. The main research question this paper seeks to answer relates to the factors responsible for changes in South Africa's water use intensity to help inform policy makers about the allocation of water within the economy over time. To highlight changes in water use intensity, the study adopts an index decomposition analysis approach as in Di Cosmo, Hyland and Llop (2012). Decomposition methodology is an extensively employed tool, particularly in resource/materials related modeling and research over the last two decades. (See the studies by Hoekstra and Van den Bergh (2003) and Ma and Stern (2008) for an extensive survey of the advantages and constraints of the various decomposition methodologies.)

\subsection{Decomposition through the Fisher Ideal Index}

The study adopts the Fisher Ideal Index approach to perform a decomposition analysis. The main advantage of this method is that it does not involve any residual terms, which would make it difficult to interpret the relative importance of structural and intensity (technical) effects. 
Specifically, Ang and Zhang (2000) emphasise that perfect decomposition methods are preferred in the case of two-factor decomposition owing to their theoretical foundation and adaptability, as well as the ease with which their results can be interpreted. In this study, changes in South Africa's water use $\left(w_{t}\right)$ are decomposed into structural and intensity components. Following the decomposition literature, the research problem is set in terms of total water use $(W)$ and total production $(Y)$, as well as subindices for economic sector $(i)$ and years $(t)$. Thus, the aggregate water use intensity $(w)$ can be written as:

$$
w_{t}=\frac{w_{t}}{Y_{t}}=\sum_{i}^{n} \frac{w_{i t}}{y_{i t}} \frac{Y_{i t}}{Y_{t}}=\sum_{i}^{n} w_{i t} S_{i t}
$$

equation (1)

Equation 1 indicates that a change in $\mathrm{w}_{t}$ may be due to changes in water intensity $\left(\mathrm{w}_{i t}\right)$ and/or structural composition $\left(s_{i t}\right)$. One of the main practical advantages of this approach is that, by construction, the water uses in the different sectors need to form a partition (i.e., they must not overlap), but the measures of economic activities do not need to satisfy this condition. In fact, they do not even need to be expressed in the same units. This facilitates the identification of good indicators to account for the structural composition $\left(s_{i t}\right)$. Following the theory on index numbers, dividing equation (1) by the aggregate water intensity for a base year $\left(w_{0}\right)$ allows a perfect decomposition of the aggregate water use intensity index into intensity $\left(F^{\text {int }}\right)$ and structural $\left(F^{\text {str }}\right)$ indices with no residual. The result, the Fisher Ideal Index, is a geometric mean of the Laspeyres and Paasche price indices.

The Laspeyres indices are:

$$
\begin{aligned}
& L_{t}{ }^{a c t}=\sum n_{i} \mathbf{W}_{i 0} S_{i t} / \sum n_{i} \mathbf{W}_{i 0} S_{i 0} \\
& L_{t}{ }^{e} f^{f}=\sum n_{i} \mathbf{W}_{i t} S_{i 0} / \sum n_{i} \mathbf{W}_{i 0} S_{i 0}
\end{aligned}
$$

equation (2.1), equation (2.2),

and the Paasche indices are:

$$
\begin{aligned}
& P_{t}^{a c t}=\sum n_{i} \mathbf{W}_{i t} S_{i t} / \Sigma n_{i} \mathbf{W}_{i t} S_{i 0} \quad \text { equation (2.3), } \\
& P_{t}{ }^{e f f}=\sum n_{i} \mathbf{W}_{i t} S_{i t} / \sum{ }_{i} \mathbf{W}_{i 0} \quad \text { equation (2.4). }
\end{aligned}
$$

The Laspeyres indices use a base period fixed weight while the Paasche indices use an end period. The Fisher Ideal Indices are then given by:

$$
\begin{aligned}
& F_{t}{ }^{a c t}=\sqrt{L_{t}}{ }^{a c t} P_{t}{ }^{a c t} \\
& F_{t}{ }^{e f f}=\sqrt{L_{t}}{ }^{e f f} P_{t}{ }^{e f f}
\end{aligned}
$$

Fischer (1921) showed that this index satisfied perfect decomposition of an expenditure index into a price and quantity component. In the context of this study, the Fischer Ideal index provides a perfect decomposition of South Africa's aggregate water use intensity index.

$$
\mathrm{w}_{t} / \mathrm{w}_{0} \equiv I_{t}=F_{t}{ }^{\mathrm{str}} F_{t}{ }^{\mathrm{int}}
$$

equation (4)

By taking the logarithm of equation (4), it is possible to observe the additive contribution of the structural effect $\left(F_{t}^{\text {str }}\right)$ and the intensity effect $\left(F_{t}{ }^{\text {int }}\right)$ to the total variation in water use per output unit $\left(I_{t}\right)$. This decomposition suggests a way to attribute changes in water consumption arising from improvements in water use intensity. Water savings $(\Delta W t)$ due to changes in water intensity are then defined as:

$$
\Delta W_{t}=W_{t}-\hat{W_{t}}
$$

equation (5)

where $W_{t}$ is actual water use and $\hat{W_{t}}$ is the water use that would have occurred had water use remained at its 1980 level. The study attributes the change in water use between intensity and economic structure as follows:

$$
\Delta W_{t}=\Delta W_{t}\left[\ln \left(F_{t}^{s t r}\right) / \ln \left(I_{t}\right)\right]+\Delta W_{t}\left[\ln \left(F_{t}^{i n t}\right) / \ln \left(I_{t}\right)\right] F t \equiv \Delta W_{t}^{s t r}+\Delta W_{t}^{\text {int }}
$$

equation (6)

\subsection{Data}

Data on total water use was derived from two main sources, namely various publications by the Department of Water Affairs (formerly the Department of Water Affairs and Forestry) and the Council for Scientific and Industrial Research. In Water resource accounts for South Africa: 2000, 
published by Statistics South Africa, the economy is divided into six water-using sectors (namely agriculture, mining, power generation, bulk industrial, other commercial and industrial and households). These accounts were relied upon to benchmark water use by economic activity for the years: 1980, 1991, 1997, 2000 and 2010. To build the water indices, the methodology requires that there should be no missing values in sectoral water use. Thus, for years with missing values, the study inputs these missing values with estimations based on the compound growth rate method as described in the expression: $y_{t}=y_{t-l}\left(1+g_{y}\right)^{l}$. In this expression $y$ represents the variable with missing/zero values, $t$ the period, $l$ the number of periods from the last not missing/zero value, and $g$ the growth rate of the variable of interest. In order to preserve trends, the study has therefore adopted the compound rate of the growth method. The real economic output information for the economy and per sectoral contribution is obtained from the Quantec databases. The data on investment (real gross fixed capital formation, excluding residential, 2005 prices) and capital stock (real productive capital stock, total excluding residential, 2005 prices) have been taken from the South African reserve bank historical data archives.

\section{$4 \quad$ Empirical results}

First up are the results of the Fisher decomposition analysis of South Africa's water use intensity computed by partitioning the country's aggregate water use into agricultural, mining, industrial, commercial and residential subsectors through the assignment of appropriate economic activity measures to each of these water-using sectors (refer to the Appendix 1 for further particulars). Thereafter, the results of the decomposition analysis are interrogated through regression techniques to determine the main drivers of change in South Africa's aggregate water use intensity.

\subsection{Water intensity trends}

Figure 3 depicts the results for the South African water indices with 1980 serving as the base year in the analysis. Aggregate water intensity in 2012 is calculated to be 44 per cent of the intensity level in 1980. Using equation (6), the study allocates the change in the country's water use (relative to the amount that would have been consumed had water use remained at its 1980 level) between intensity (technical) and structural effects. The structural index is 93 per cent of the level it was in 1980 while the intensity index is 51 per cent of its 1980 level. In other words, had the composition of economic activity not changed between 1980 and 2012, water use intensity would have been 51 per cent of its 1980 level. The 49 per cent reduction in South Africa's aggregate water use was due to decreases in water intensity. Similarly, had water use intensity been fixed at its 1980 levels for all sectors, changes in the structure of economic activity would have led to a 7 per cent decrease in water use.

Figure 3

South African water use indices

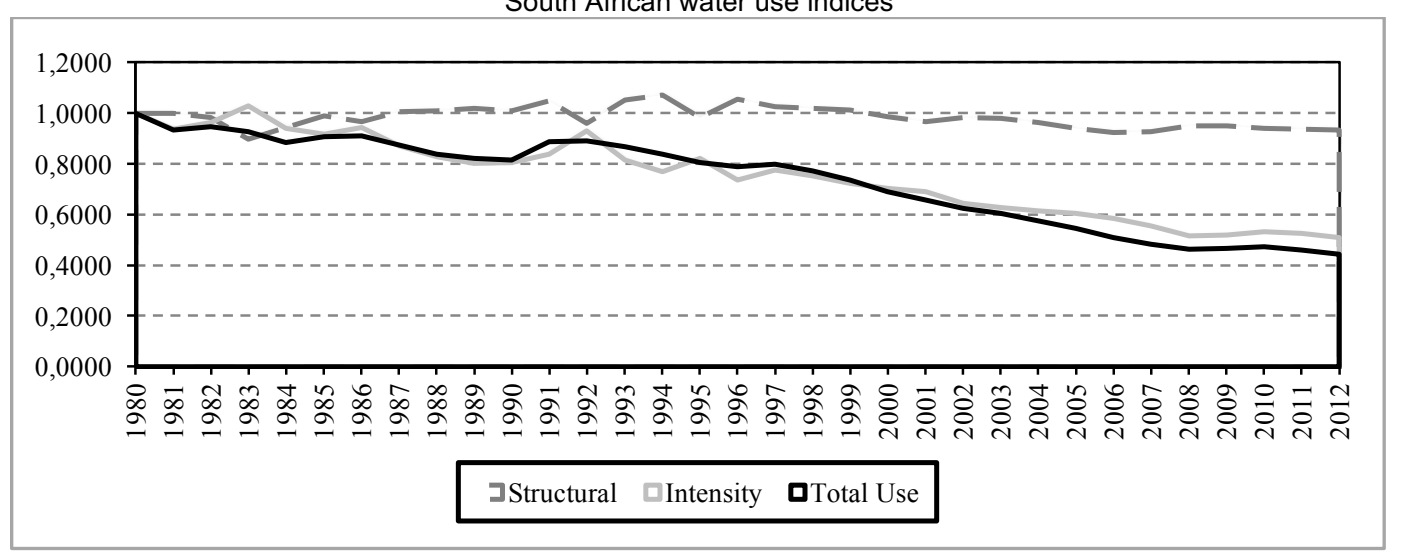

Source: Author's own calculations 
Based on the decomposition analysis, the bulk of the 66 per cent reduction in water use arises from changes that can be attributed to decreases in intensity of use. In contrast, changes in the composition of economic activity in South Africa have only a minor impact on the country's aggregate water use.

Figure 4

Water savings relative to use in 1980

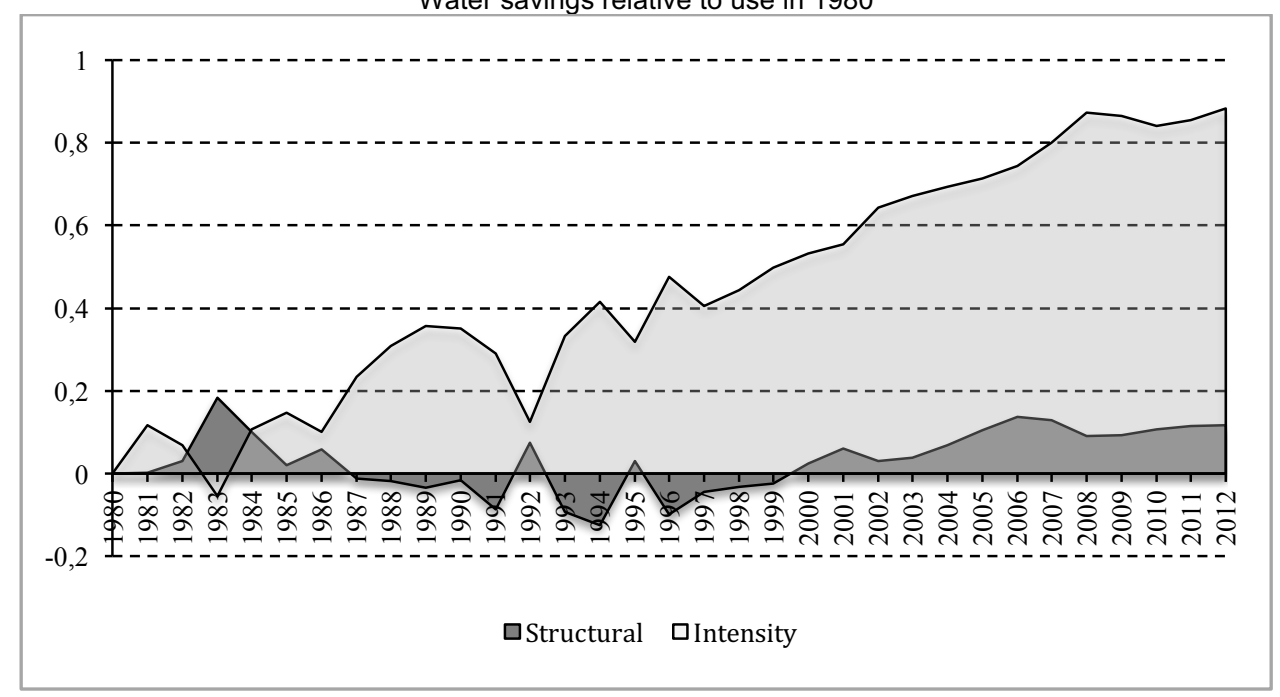

Source: Author's own calculations

Figure 4 shows the contributions of changes in intensity of use and the structure of economic activity on water savings between 1980 and 2012. Throughout the period under investigation changes in water use can be attributed almost entirely to reductions in intensity of water use. It is important to emphasise that the decomposition is conditional on the particular choice of waterusing sectors identified in the analysis used in the partitioning of the data.

\subsection{Drivers of South Africa's water use intensity}

The decomposition results highlight the significance of technological improvements in driving changes in South Africa's water use intensity. The intensity (or technical effect) is the dominant factor that contributes to downward pressure on the country's water consumption. This is because the intensity effect works in either of two ways (or a combination thereof), namely, (1) technical progress can motivate users of water to substitute other production inputs for water resources and/or (2) it could encourage them to decrease their water usage through the recycling of water use. Policy makers should, therefore, implement appropriate policies to promote technical progress and the re-use of water resources. Although reductions in water use intensity embodied in new capital may well account for a proportion of the intensity (technical) effect, one would still expect this effect to be relatively small and constant over time, and not a driver of the large short-run fluctuations in the intensity effect.

Turning the study focus on the intensity effect, the decomposition analysis seems to show that water intensity rises during periods of low economic growth and falls in periods of high economic growth. It would seem from casual observation that this effect is due to higher levels of investment in periods of high economic growth. With the new capital stock being less water-intensive than that which it replaces, there has been a corresponding marked improvement in water use intensity in the economy. Such an explanation does not, however, appear to make intuitive sense. This is because the proportion of the total capital stock replaced in any year, even in a year when economic growth is high, is relatively low. Furthermore, it is not clear why water use intensity 
would rise even in periods when investment is low. For even in years when investment in South Africa has been low, the level of investment has been more than enough to offset depreciation, thereby lifting the country's capital stock.

Figure 5

Capacity utilisation and the intensity effect

Ratio of real productive capital stock (excluding residential) to real GDP, intensity effect index (1980 base year=100)

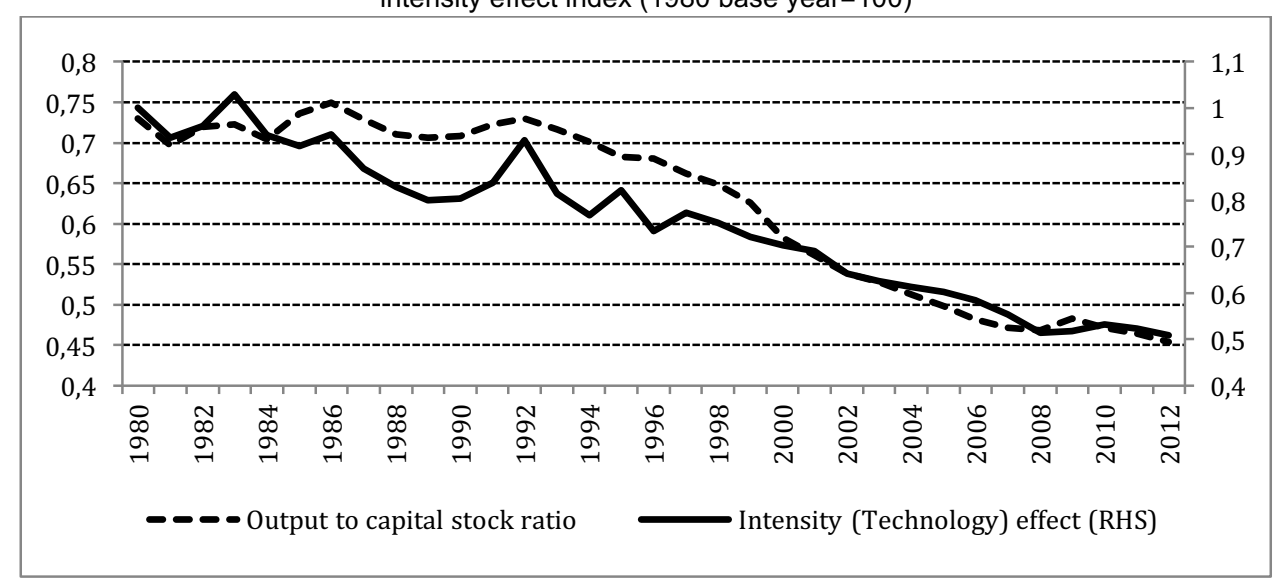

Source: Author's own calculations

On closer examination it appears that variations in South Africa's water use intensity are more likely to be due to changes in capacity utilisation (see figure 5). A relatively high proportion of water use in economic activities is fixed, with water being used for cooling, heating, cleaning purposes etc. The remainder reflects changes in production levels, and represents the variable proportion of total water costs. It is changes in these variable costs that reflect short-run changes in the aggregate level of economic activity. Because of the fixed component, total water use will not fluctuate as much as output. Hence, water use intensity is relatively volatile, reflecting changes in output or capacity utilisation. The study derives capacity utilisation for the economy by taking the ratio of capital stock/output. In fact the ratio represents the inverse of capacity utilisation. The household sector is excluded from the analysis by the use of gross fixed capital formation excluding residential investment within the economy.

Figure 5 indicates that capacity utilisation and the intensity effect track each other fairly closely. Remember that the intensity (technical) effect index represents the movement in the residual component of the water/output ratio after adjustment for industrial structure. Hence, the intensity (technical) effect index is a good indicator of the intensity of water use. Note that a rise in the capital/output ratio indicates a fall in capacity utilisation, and vice versa. Hence, Figure 5 reveals that the water/output ratio falls as capacity utilisation rises, and rises as capacity utilisation falls. This trend is consistent with the notion of having separate fixed and variable costs associated with water usage.

What remains to be explained is why the water/output ratio would actually rise during periods when net investment is positive. To interrogate this, the study runs a number of regressions, to verify the magnitude of the various relationships. The regression variables and equations are set out in Appendix B. Regressing the intensity effect on the capital/output ratio generates a $\mathrm{R}^{2}$ of 0.74. Regressing the intensity effect on investment produces an $R^{2}$ of only 0.07 . The $R^{2}$ of both series together against the intensity effect is 0.82 . To check that this is not a result of multicollinearity between investment and the capital/output ratio, the one is regressed against the other; at 0.004 , the $\mathrm{R}^{2}$ does not suggest a significant relationship between these two series. The regression analysis therefore indicates that the intensity effect, or water use per unit of output, is affected by both capacity utilisation and investment, with the equation being: 
where:

IE is the intensity (technical) effect index

$\mathrm{KS} / \mathrm{Y}$ is the real productive capital stock/output ratio

GFKF is the real gross fixed capital stock (investment).

Given that the coefficients of the equation are in logs, we can interpret these as elasticities. Hence a 1 per cent rise in the capital/output ratio can be expected to result in a 1.1 per cent increase in the water/output ratio, while a 1 per cent rise in GFKF will result in a 0.24 per cent fall in the water/output ratio. Hence both factors are at work. A rise in capacity utilisation will lower the intensity of water use, as will a fall in investment. The analysis therefore suggests that when investment levels in South Africa are lower than in the previous year, the contribution from investment causes a rise in the water/output ratio. This development still appears to be counterintuitive. As mentioned earlier, even in years when investment falls in South Africa, the level of investment is still substantial. It therefore does not seem to follow that an easing in the level of investment will necessarily result in a rise in the water/output ratio. On closer inspection investment is found to be highly correlated with output, with an $\mathrm{R}^{2}$ of 0.85 . Hence, investment may have entered into equation (7) because of its correlation with output, which is the denominator of the dependent variable in this equation, namely: the water/output ratio. In an initial attempt to remove this effect, the regression analysis included dividing GFKF by output (see equation 5 in Appendix B). This did not, however, have a notable impact on the performance of the regression equation.

Figure 6

Capital stock and water use

Real productive capital stock (thousands of rand, excluding residential), water use $\left(\mathrm{m}^{3}\right.$, excluding residential, adjusted for structural effect)

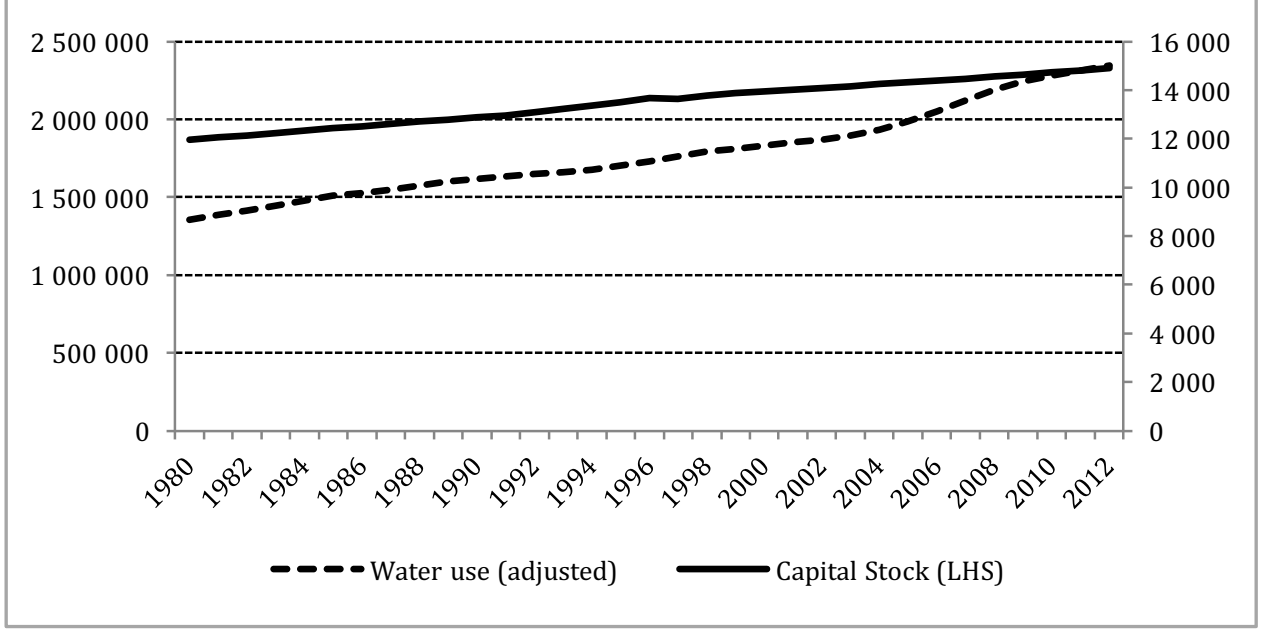

Source: Author's own calculations

Suppose that the output level is not used as the denominator of water use (the dependent variable) in equation (7) but instead the regression analysis simply represents the variables of interest in the study in levels. That is, the analysis represents water use as a function of the capital stock and the investment level, as in equation (8).

$$
\mathrm{W}=\mathrm{f}\left(\mathrm{KS}_{\mathrm{t}-1}, \mathrm{GFKF}\right)
$$

This representation of water use makes intuitive sense, especially if the economy's capital stock is lagged by one year. That is, water use is then dependent on last year's capital stock and this year's increment to the capital stock (investment). This suggests that the capital stock level generally 
determines water use. But do the data back this up? Figure 6 seems to support this view. In contrast, the correlation between water use and output is not as high (see Figure 7). Water use and output tended to diverge in the early 1990s when capacity utilisation was low in South Africa.

Figure 7

Output and water use

Real GDP ( $R$ thousands, 2005 prices), water use $\left(\mathrm{m}^{3}\right.$, excluding residential, adjusted for structural effect)

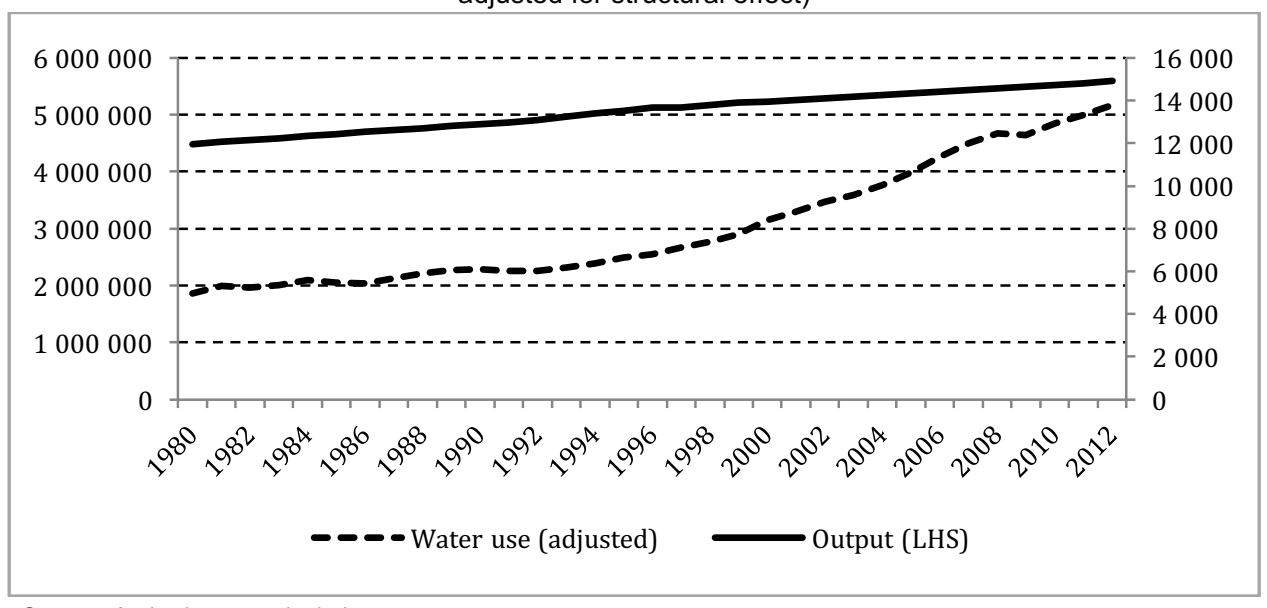

Source: Author's own calculations

In fact, this chart sheds light on changes in the intensity (technical) effect (the water/output ratio) as reported earlier. It seems clear now that the rise in the water/output ratio in the mid 1980s and early 1990s was due almost entirely to falls in output. (The regression results for the intensity (technical) effect equation pick up this relationship via capacity utilisation, which was low in this period.) If, as the regressions analysis suggests, water use generally reflects the level of capital stock, this would support the view that the fixed component of water use is relatively high. In other words water use in economic activities is related to the machinery, equipment and infrastructure that is in operation, rather than being simply a function of the output that is being generated. In view of this, the study adopts a co-integration approach, estimating a long-run equation relating water use to the capital stock, output, and capacity utilisation. The best fit in respect of the long-run equation relates the level of South Africa's water use to the capital stock of the economy (see Appendix B). The $\mathrm{R}^{2}$ for this equation is high, at 0.92 . This supports the view expressed above that water use is generally related to the level of capital stock. An interesting feature of the long-run equation is the coefficient on the capital stock, which at 0.963 , is less than 1. This implies that a 1 per cent rise in the capital stock will be accompanied by a 0.96 per cent rise in water use. Hence, the equation shows that the capital stock is becoming less water-intensive although the rate of change is slow.

\section{Conclusion}

In the face of South Africa's growing water scarcity, water conservation and the effective management of water use should be priority focus areas of water policy in the country. There is an urgent need to introduce market-based incentives to optimise the allocation of scarce water resources among competing uses. These economic incentives should target water-stressed areas with the objective of encouraging a shift in water use from economic activities with low water efficiency values to activities with high water efficiency values.

Unfortunately, under South Africa's previous water legislation, the pricing of water did not take into account either the real cost of managing water, the cost of supplying water or the scarcity value of water. MacKay (2003) suggests that the capital costs of government water schemes 
supplying mainly agricultural water users (and many urban bulk water suppliers and industrial users) were either financed or heavily subsidised by the government. Additionally, operational and maintenance costs were often not fully recovered from these water users (MacKay 2003:64).

Ultimately the management of South Africa's water resources should involve using information obtained from an analysis of water use intensity to design and develop policies to help allocate water to its most productive use, while maintaining ecosystem functions, human well-being and social equity. The difficulty lies in the implementation of policies that encourage users of water within the country to use water in a manner reflective of its scarcity value. Such policies will help South Africa achieve the required water savings with minimal disruption to the economy. The set of policy solutions includes both technical improvements to increase supply and measures to reduce the intensity of water use.

The regression analysis undertaken as part of the study on economy-wide water use intensity has shown that in the long run, water use in the South African economy is related to the capital stock. The analysis also suggests that the capital stock is becoming more water-efficient over time, but that this change is gradual. The study thus suggests that in the long run it is the relationship between water and the economy's capital stock that has to be changed, if South Africa is to become more water wise. The regression analysis furthermore suggests that monitoring South Africa's water/output ratio, and drawing strong conclusions from this regarding changes in water use intensity, is fraught with difficulties.

The study recognises that markets and water prices are not necessarily the ideal mechanism for distributing an essential good such as water. Water authorities in South Africa may have sound reasons for using other allocation mechanisms which include the need to ensure that ecosystems have adequate water to function and deliver services. Only after adequate water resources are made available to meet basic human needs and to safeguard ecosystem health should water be allocated for other uses within the economy based upon the concept of water productivity (UNEP, 2012). It is nevertheless recognised that regulatory mechanisms that include monitoring, volumetric metering and enforcement of legal limits on water use and pollution are often costly and vary in their efficacy owing to inaccurate information between regulators and water users (UNEP, 2012). The study supports the use of a combination of approaches to water resource management, including information-based tools such as labeling and the education of producers and consumers. Operating together, the mixture of water resource management tools should incentivise innovation and the adoption of new processes and technologies, reducing the intensity of water use across all sectors of the economy and thereby assisting policy makers to decouple water use and its impact on South Africa's economic growth.

\section{Endnote:}

* Correspondence to: kohler@ukzn.ac.za

\section{Acknowledgement}

The author acknowledges the financial support of Economic Research Southern Africa without which this study would not have been possible.

\section{References}

ANG, B.W. \& ZHANG, F.Q. 2000. A survey of index decomposition analysis in energy and environmental studies. Energy, 25(12):1149-1176.

BAUMANN, D.D., BOLAND, J.J. \& SILMS, J.H. 1980. The problem of defining water conservation. The Cornett Papers, 13(2):125-134.

COUNCIL FOR SCIENTIFIC AND INDUSTRIAL RESEARCH (CSIR). 2001. Water resource accounts for South Africa. Report to Statistics South Africa and the Department of Environmental Affairs and Tourism. Report No. ENV-P-C 2001-050. 
CUMMINGS, R.G. \& NERCISSIANTZ, V. 1992. The use of water pricing as a means for enhancing water use efficiency in irrigation: Case studies in Mexico and the United States. Natural Resource Journal, 32:731755.

DEPARTMENT OF WATER AFFAIRS AND FORESTRY (DWAF). 1998. National Water Act 36 of 1998. Pretoria: Government Printer.

DEPARTMENT OF WATER AFFAIRS AND FORESTRY. 2000. Development of a waste discharge charge system. Framework document. (2 $2^{\text {nd }}$ edition.)

DEPARTMENT OF WATER AFFAIRS AND FORESTRY. 2004a. National water resource strategy of South Africa.

DEPARTMENT OF WATER AFFAIRS AND FORESTRY. 2004b. Water conservation and water demand management strategy for the industry, mining and power generation sectors.

DEPARTMENT OF WATER AFFAIRS. 2013. Strategic overview of the water sector in South Africa. DI COSMO, V., HYLAND, M. \& LLOP, M. 2012. Disentangling water usage in the European Union: A decomposition analysis. MPRA, Paper No. 42865.

DINAR, A., ROSEGRANT, M.W. \& MEINZEN-DICK, R.S. 1997. Water allocation mechanisms: principles and examples. World Bank Policy Research Working Paper, Paper No 1779.

DINAR, A. \& SUMRAMANIAN, A. 1998. Policy implications from water pricing experiences in various countries. Water Policy, 1:239-250.

EBERHARD, R. 2003. Economic regulation of water. Trade and Industry Monitor, 26:12-17.

HOEKSTRA, R. \& VAN DEN BERGH, J.C. 2003. Comparing structural decomposition analysis and index. Energy Economics, 25:39-64.

KING, N.A. 2004. The economic value of water in South Africa, in: BLIGNAUT, J.N. \& DE WIT, M.P. (eds.) Sustainable options: Development lessons from applied Environmental Economics. Cape Town: UCT Press.

MA, C., STERN, D.I. 2008. China's changing energy intensity trend: A decomposition analysis. Energy Economics, 30:1037-1053.

MACKAY, H. 2003. Water policies and practises. In: Reed, D \& de Wit, M. (eds.) Towards a just South Africa - The political economy of natural resources wealth. WWF and CSIR, Pretoria.

METCALF, G.E. 2008. An Empirical Analysis of Energy Intensity and Its Determinants at the State Level. The Energy Journal, 29(3):1-26.

MOOLMAN, C.E., BLIGNAUT, J.N. \& VAN EYDEN, R. 2006. Modelling the marginal revenue of water in selected agricultural commodities: A panel data approach. Agrekon, 45(1):78-88.

STATISTICS SOUTH AFRICA. 2009. Water account for South Africa: 2000. National Accounts, Environmental Economic Accounts.

TATE, D.M. 2000. Principles of water use efficiency. Council of Professional Informatics Societies, CEPIS Available at: http://www.cepis.opsoms.org/muwww/fulltext/repind48/principles/principles.html [accessed March 2016].

UNITED NATIONS (UN). 2006. System of environmental-economic accounting for water.

UNITED NATIONS ECONOMIC AND SOCIAL COMMISSION FOR ASIA AND THE PACIFIC (UN ESCAP). 2009. Eco-efficiency indicators: Measuring resource-use efficiency and the impact of economic activities on the environment.

UNITED NATIONS ENVIRONMENT PROGRAMME (UNEP). 2012. Measuring water use in a green economy. Report by the Working Group on Water Efficiency to the International Resource Panel.

UNITED NATIONS EDUCATIONAL SCIENTIFIC AND CULTURAL ORGANISATION (UNESCO). 2006. Water a shared responsibility. The United Nations World Water Development Report, 2.

\section{Appendix A}

In its analysis of South African water intensity, the study employs measures of economic activity related to the underlying water use within each of the economy's subsectors. Based on the methodology employed in Metcalf (2008), personal consumption expenditure is employed as the activity measure in the case of South Africa's residential water consumption. According to Metcalf 
(2008), this is preferable to disposable income since a portion of disposable income goes to savings that should have no discernible impact on residential water demand. In the case of South Africa's mining, commercial and industrial water use, the study employs the concept of value added for these sectors of the economy. Value added is a measure of the contribution to final production from a given sector.

Table A1 identifies the economic subsectors for which water use is analysed and presents summary statistics for the measures of economic activity of these sectors. The identified economic subsectors are employed for the purposes of the decomposition analysis as well as in the generation of statistics on sector-level water efficiency. The table thus also provides summary statistics on the data used to construct the water indices for South Africa.

Table A1

South African economic activities for the national level decomposition analysis ${ }^{(1)}$

\begin{tabular}{|c|c|c|c|c|c|c|}
\hline \multirow[b]{2}{*}{ Sector } & \multicolumn{3}{|c|}{ Economic activity } & \multicolumn{3}{|c|}{ Sector-level water intensity } \\
\hline & Measure & Mean & $\begin{array}{l}\text { Standard } \\
\text { deviation }\end{array}$ & Measure & Mean & $\begin{array}{l}\text { Standard } \\
\text { deviation }\end{array}$ \\
\hline Industrial & $\begin{array}{l}\text { Value Added in } \\
\text { Industrial Sector } \\
\text { (R million - 2005) }\end{array}$ & 885,215 & 286,209 & $\begin{array}{c}\mathrm{m}^{3} \text { per Rand } \\
\quad(2005)\end{array}$ & 1.98 & 0.56 \\
\hline Mining & $\begin{array}{l}\text { Value added in mining } \\
\text { sector } \\
\text { (R million - 2005) }\end{array}$ & 160,157 & 23,441 & $\begin{array}{l}\mathrm{m}^{3} \text { per Rand } \\
(2005)\end{array}$ & 3.40 & 0.001 \\
\hline Commercial & $\begin{array}{l}\text { Value added in } \\
\text { commercial sector } \\
\text { (R million - 2005) }\end{array}$ & $1,129,708$ & 477,321 & $\begin{array}{l}\mathrm{m}^{3} \text { per Rand } \\
(2005)\end{array}$ & 0.37 & 0.13 \\
\hline Agricultural & $\begin{array}{l}\text { Value added in } \\
\text { agricultural sector } \\
\text { (R million - 2005) }\end{array}$ & 69,187 & 20,375 & $\begin{array}{l}\mathrm{m}^{3} \text { per Rand } \\
(2005)\end{array}$ & 151.9 & 0.04 \\
\hline Residential & $\begin{array}{l}\text { Total personal } \\
\text { consumption } \\
\text { expenditures } \\
\text { (R million - 2005) }\end{array}$ & 780,714 & 241,317 & $\begin{array}{l}\mathrm{m}^{3} \text { per Rand } \\
(2005)\end{array}$ & 1.86 & 0.51 \\
\hline Total & $\begin{array}{c}\text { GDP } \\
\text { (R million - 2005) }\end{array}$ & $2,375,776$ & 846,542 & $\begin{array}{l}\mathrm{m}^{3} \text { per Rand } \\
(2005)\end{array}$ & 6.26 & 1.90 \\
\hline
\end{tabular}

Source: Water use data from DWAF and economic activity data from Quantec.

${ }^{(1)}$ Data from 1980 to 2012. Agriculture includes forestry and fishing related activities. The commercial sector includes communication, wholesale and retail trade, finance, other commercial services and public services.

Table A2 presents the water use indices for South Africa over the analysis period. 
Table A2

South African water use indices

\begin{tabular}{|c|c|c|c|}
\hline Year & Structural & Intensity & Aggregate \\
\hline 1980 & 1,0000 & 1,0000 & 1,0000 \\
\hline 1981 & 0,9992 & 0,9353 & 0,9344 \\
\hline 1982 & 0,9833 & 0,9615 & 0,9448 \\
\hline 1983 & 0,8979 & 1,0303 & 0,9281 \\
\hline 1984 & 0,9433 & 0,9409 & 0,8842 \\
\hline 1985 & 0,9886 & 0,9178 & 0,9065 \\
\hline 1986 & 0,9676 & 0,9433 & 0,9109 \\
\hline 1987 & 1,0062 & 0,8692 & 0,8754 \\
\hline 1988 & 1,0095 & 0,8287 & 0,8382 \\
\hline 1989 & 1,0190 & 0,8010 & 0,8200 \\
\hline 1990 & 1,0087 & 0,8048 & 0,8135 \\
\hline 1991 & 1,0486 & 0,8388 & 0,8874 \\
\hline 1992 & 0,9588 & 0,9300 & 0,8888 \\
\hline 1993 & 1,0511 & 0,8151 & 0,8663 \\
\hline 1994 & 1,0698 & 0,7682 & 0,8380 \\
\hline 1995 & 0,9825 & 0,8229 & 0,8054 \\
\hline 1996 & 1,0544 & 0,7349 & 0,7893 \\
\hline 1997 & 1,0251 & 0,7740 & 0,7991 \\
\hline 1998 & 1,0177 & 0,7528 & 0,7705 \\
\hline 1999 & 1,0135 & 0,7222 & 0,7358 \\
\hline 2000 & 0,9867 & 0,7032 & 0,6900 \\
\hline 2001 & 0,9660 & 0,6914 & 0,6573 \\
\hline 2002 & 0,9827 & 0,6421 & 0,6248 \\
\hline 2003 & 0,9783 & 0,6267 & 0,6050 \\
\hline 2004 & 0,9622 & 0,6136 & 0,5758 \\
\hline 2005 & 0,9413 & 0,6030 & 0,5442 \\
\hline 2006 & 0,9238 & 0,5853 & 0,5091 \\
\hline 2007 & 0,9282 & 0,5540 & 0,4822 \\
\hline 2008 & 0,9499 & 0,5140 & 0,4639 \\
\hline 2009 & 0,9484 & 0,5185 & 0,4669 \\
\hline 2010 & 0,9405 & 0,5325 & 0,4730 \\
\hline 2011 & 0,9358 & 0,5237 & 0,4594 \\
\hline 2012 & 0,9345 & 0,5084 & 0,4430 \\
\hline
\end{tabular}

\section{Appendix B: Water use regression results}

\section{B.1 Regression variables}

The regressions variables are denoted as follows:

IE Intensity effect index

AdjW adjusted water use

KS Real productive capital stock, total excluding residential, 2005 prices

GFKF Real gross fixed capital formation, excluding residential, 2005 prices

Y Real GDP, 2005 prices 
B.2 Intensity effect results (T-statistics presented in italics)

Intensity effect versus capital stock/output ratio

$$
\begin{gathered}
\ln (\mathrm{IE})=3.194+1.180 \ln (\mathrm{KS} / \mathrm{Y}) \\
(33.09) \quad(6.46) \\
\mathrm{R}^{2}=0.74
\end{gathered}
$$

Intensity effect versus capital stock/output ratio and gross fixed capital formation

$$
\begin{gathered}
\ln (\mathrm{IE})=5.052+1.095 \ln (\mathrm{KS} / \mathrm{Y})-0.235 \ln (\mathrm{GFKF}) \\
(13.25) \quad(7.31) \quad(-2.53) \\
\mathrm{R}^{2}=0.82
\end{gathered}
$$

Intensity effect versus gross fixed capital formation

$$
\begin{gathered}
\ln (\mathrm{IE})=4.572-0.098 \ln (\mathrm{GFKF}) \\
(6.57) \quad(-1.11) \\
\mathrm{R}^{2}=0.07
\end{gathered}
$$

Capital stock/output ratio versus gross fixed capital formation

$$
\begin{gathered}
\ln (\mathrm{KS} / \mathrm{Y})=-0.536+0.019 \ln (\mathrm{GFKF}) \\
(-0.73) \quad(-0.18) \\
\mathrm{R}^{2}=0.004
\end{gathered}
$$

Intensity effect versus capital stock/output ratio, gross fixed capital formation/output ratio

$$
\begin{gathered}
\ln (\mathrm{IE})=6.568+1.285 \ln (\mathrm{KS} / \mathrm{Y})-0.113 \ln (\mathrm{GFKF} / \mathrm{Y}) \\
(21.72) \quad(5.07) \quad(-2.54) \\
\mathrm{R}^{2}=0.84
\end{gathered}
$$

B.3 Water use results (T-statistics presented in italics)

$$
\begin{gathered}
\ln (\operatorname{Adj} E)=-4.591+0.963 \ln (\mathrm{KS}) \\
(-5.45) \quad(10.05) \\
\mathrm{R}^{2}=0.92
\end{gathered}
$$

